\title{
TIỀM NĂNG ÚNG DỤNG XẠ KHUẨN TRONG XỬ LÝ NƯỚC THẢI GIẢU TINH BộT
}

\author{
NGUYỄN THI DIỆU HẠNH ${ }^{1}$, BÙI THẢO VY ${ }^{1}$, ĐẶNG LƯƠNG PHƯƠNG THẢO ${ }^{1}$, NGUYỄN THỊ \\ THANH THÚY ${ }^{1}$, BÙI THỊ LUYẾN ${ }^{2}$, NGUYỄN THANH HẢI ${ }^{2}$, NGUYỄN NGỌC ẨN ${ }^{1}$, PHAM TẤN VIẸT ${ }^{1}$ \\ ${ }^{l}$ Viện Công nghệ Sinh học và Thưc phẩm, Truờng Đại học Công Nghiệp Tp. Hồ Chí Minh \\ ${ }^{2}$ Truờng Đại học Khoa học Tự nhiên, Đại học Quốc gia Tp. Hồ Chí Minh \\ phamtanviet@iuh.edu.vn
}

Tóm tắt: Xạ khuẩn là nhóm vi khuẩn có khả năng sinh tổng hợp nhiều hợp chất có hoạt tính sinh học và đã được ứng dụng trong nhiều lĩnh vực khác nhau. Trong nghiên cứu này, 20 chủng xạ khuẩn đã được phân lập và 10 chủng xạ khuẩn có khả năng sinh tổng hợp amylase ngoại bào đã được tuyển chọn. Qua định danh sơ bộ, chúng tôi xác định được 2 chủng VTXK10 và VTXK11 có sự tương đồng với xạ khuẩn Amycolaptosis sp., trong khi chủng RBXK3 có độ tương đồng với chủng xạ khuẩn Streptomyces canus. Chế phẩm xạ khuẩn được sử dụng xử lý nước thải giàu tinh bột, kết quả cho thấy chỉ số $\mathrm{BOD}_{5}$ giảm 61,6$65,1 \%$, giá trị COD giảm 48,7-53,8\% và hàm lượng tinh bột tương đối trong nước thải giảm 31,1-38,4\%. Ngoài ra, $\mathrm{pH}$ của nước thải sau xử lý đã tiệm cận với giá trị trung tính. Thử nghiệm ảnh hưởng của nước thải được xử lý lên sự phát triển của hạt đậu xanh cho thấy hạt đậu xanh phát triển tương tự như trong đối chứng được tưới với nước cất. Nghiên cứu này đã cho thấy tiềm năng ứng dụng của xạ khuẩn trong xử lý nước thải giàu tinh bột bằng phương pháp sinh học, góp phần bảo vệ môi trường bền vững.

Từ khóa: Xạ khuẩn, amylase, nước thải, Streptomyces canus, Amycolaptosis sp.

\section{POTENTIAL APPLICATION OF ACTINOMYCES IN TREATMENT OF STARCH- RICH WASTEWATER}

\begin{abstract}
Actinomyces is a group of bacteria that can produce many bioactive compounds and has been used in many different fields. In this study, 20 actinomycetes strains were isolated and 10 actinomycetes strains producing extracellular amylase were selected. Preliminary identification of the actinomycetes strains by analysis of 16S rDNA gene sequences showed that two strains of VTXK10 and VTXK11 display high homology to Amycolaptosis sp., while RBXK3 has high similarity with Streptomyces canus. The treatment of starch-rich wastewater with actinomycetes mixture showed significant reduction of $\mathrm{BOD}_{5}$ by 61.6-65.1\%, COD by 48.7-53.8\%, relative starch content by 31.1-38.4\%, and resulted in balancing the $\mathrm{pH}$ value of wastewater in neutral range. The effect of treated wastewater on development of green beans was found to be similar to the control distilled water. This study has shown the potential application of actinomyces in treatment of starch-rich wastewater, contributing to sustainable environmental protection.
\end{abstract}

Keywords: Actinomyces, amylase, wastewater, Streptomyces canus, Amycolaptosis sp.

\section{GIỚI THIỆU}

Ô nhiễm nước là vấn đề quan trọng trên toàn thế giới cần được quan tâm hiện nay. Cùng với sự phát triển của các ngành công nghiệp, việc xử lý nước thải ngày càng được quan tâm. Nước thải không được xử lý hoặc xử lý không triệt để sẽ ảnh hưởng đến hệ sinh thái của các sinh vật thủy sinh, ảnh hưởng đến nguồn nước ngầm và dẫn đến việc ô nhiễm đất canh tác nông nghiêp cũng như sức khỏe của người và động vật trên toàn cầu [1-3]. Do đó, phương pháp xử lý nước thải hiệu quả, an toàn, ít tốn kém với các thiết bị đơn giản là nhu cầu cấp thiết để thay thế các phương pháp đang được sử dụng hiện nay. Trong các phương pháp xử lý nước thải hiện nay, các phương pháp sinh học có ứng dụng vi sinh vật với các ưu điểm nổi bật ngày càng được quan tâm. Vi sinh vật đóng vai trò quan trọng trong vòng tuần hoàn và chuyển hóa vật chất từ việc phân hủy các hợp chất hữu cơ đến việc chuyển hóa các kim loại nặng, các ion khoáng trong sinh quyển. Việc ứng dụng các loại vi sinh vật, đặc biệt là nhóm xạ khuẩn trong xử lý nước thải đã được báo cáo trong nhiều nghiên cứu trước đây [1-5].

Xạ khuẩn được xếp vào nhóm vi sinh vật có lợi và được sử dụng trong sản xuất các chất trao đổi thứ cấp, được ứng dụng nhiều trong y dược và nông nghiệp [6]. Các hợp chất thứ cấp có nguồn gốc từ xạ khuẩn như 
chất kháng sinh, kháng khối u, các hợp chất kháng khuẩn, kháng oxy hóa, các enzyme và các chất ức chế enzyme, các chất điều hòa sinh trưởng thực vật và vitamin ngày càng được nghiên cứu rộng rãi và đã chứng minh được tầm quan trọng của đối tượng vi sinh vật này trong thực tiễn [6-9]. Khả năng sinh tổng hợp nhiều loại enzyme ngoại bào khác nhau của xạ khuẩn cũng như khả năng chịu nhiệt của chủng vi sinh vật này được nghiên cứu nhiều và ứng dụng trong việc xử lý các chất thải, nước thải trong tự nhiên $[10,11]$. Nước thải từ các công ty sản xuất tinh bột, nhà máy chà gạo, cơ sở sản xuất các sản phẩm tinh bột có hàm lượng chất hữu cơ hòa tan cao, các nguồn nước thải này có khả năng gây ô nhiễm môi trường nghiêm trọng nếu không được xử lý hiệu quả. Xạ khuẩn được ghi nhận có mật độ phong phú trong các nguồn nước thải này và các chủng xạ khuẩn phân lập từ các nguồn thải này có khả năng sinh tổng hợp amylase hoạt tính cao [12]. Do đó, việc phân lập và chọn lọc các chủng xạ khuẩn có khả năng tham gia vào chế phẩm vi sinh để xử lý nước thải chứa các hợp chất hữu cơ như tinh bột là cần thiết, giúp cho quá trình xử lý dạng nước thải này đơn giản và hiệu quả, giảm ô nhiễm môi trường nước, không gây độc hại cho các sinh vật thủy sinh. Trong nghiên cứu này, chúng tôi tiến hành tuyển chọn các chủng xạ khuẩn có khả năng sinh tổng hợp enzyme amylase có hoạt tính cao và ứng dụng trong xử lý nước thải giàu tinh bột từ làng nghề sản xuất bún cho thấy hiệu quả khả quan. Các chỉ số $\mathrm{BOD}_{5}, \mathrm{COD}$, hàm lượng tinh bột, $\mathrm{pH}$ cũng như tác động lên sự phát triển của thực vật đã được ghi nhận có hiệu quả tốt hơn so với nước thải ban đầu không được xử lý với xạ khuẩn. Kết quả nghiên cứu cho thấy tiềm năng ứng dụng của xạ khuẩn trong việc xử lý nước thải giàu tinh bột, hướng tới việc giảm ô nhiễm môi trường bằng biện pháp an toàn và hiệu quả.

\section{VẬT LIỆU \& PHƯƠNG PHÁP NGHIÊN CÚU \\ 1.1. Phân lập xạ khuẩn}

Các chủng xạ khuẩn được phân lập từ các mẫu đất tại các làng nghề làm bún ở tỉnh Tiền Giang. Các mẫu đất được pha loãng theo bậc 10 ở nhiều độ pha loãng khác nhau trong nước cất vô trùng, $0,1 \mathrm{ml}$ dung dịch đất sau pha loãng ở bậc pha loãng $10^{-6}$ được trải đều lên đĩa Petri có chứa môi trường Gause $\mathrm{I}$ (tinh bột tan $20,0 \mathrm{~g} ; \mathrm{K}_{2} \mathrm{HPO}_{4}$ 0,5 g; $\mathrm{MgSO}_{4} .7 \mathrm{H}_{2} \mathrm{O} 0,5 \mathrm{~g} ; \mathrm{KNO}_{3} 1,0 \mathrm{~g} ; \mathrm{NaCl}$ 0,5 g; $\mathrm{FeSO}_{4}$ 0,1 g; agar 20,0 g; nước cất đủ $1000 \mathrm{ml}$; pH 7,2-7,4), và ủ ở $37^{\circ} \mathrm{C}$ trong 5-10 ngày. Các khuẩn lạc đặc trưng của xạ khuẩn được chọn lựa và tiến hành cấy ria trên môi trường Gause I cho đến khi thu được các chủng xạ khuẩn thuần, không nhiềm tạp vi sinh vật khác. Các chủng xạ khuẩn được bảo quản ở $4^{\circ} \mathrm{C}$ để thực hiện các thí nghiệm tiếp theo.

\section{2. Đánh giá sơ bộ khả năng sinh tổng hợp amylase}

Khả năng sinh tổng hợp amylase của các chủng xạ khuẩn được đánh giá sơ bộ thông qua vòng phân giải tinh bột trên môi trường thạch Gause $\mathrm{I}$ khi có sự hiện diện của dung dịch lugol. Các chủng xạ khuẩn được nuôi cấy trong môi trường Gause $\mathrm{I}$ ở $37^{\circ} \mathrm{C}$ trong 10 ngày. Sau thời gian nuôi ủ, vòng phân giải được kiểm tra bằng thuốc thử lugol. Khả năng sinh tổng hợp amylase để phân giải tinh bột của các chủng xạ khuẩn được xác định bằng cách so sánh độ lớn vòng phân giải $\mathrm{A}=\mathrm{D}-\mathrm{d}$ với $\mathrm{D}$ là đường kính vòng phân giải và $\mathrm{d}$ là đường kính khuẩn lạc của xạ khuẩn [13].

\section{3. Định danh xạ khuẩn}

Căn cứ vào kết quả khảo sát sơ bộ về khả năng sinh tổng hợp amylase, các chủng xạ khuẩn được chọn sẽ được nuôi trên môi trường Gause I trong 10 ngày ở $37^{\circ} \mathrm{C}$ và quan sát hình thái vi thể. Cấu trúc cuống sinh bào tử được quan sát trên tiêu bản phòng ẩm bằng kính hiển vi quang học ở độ phóng đại 1000 lần. Các chủng xạ khuẩn được định danh ở mức phân tử bằng phương pháp giải trình tự đoạn gen 16S-rRNA với cặp mồi chuyên biệt $27 \mathrm{mF}$ (5'-AGAGTTTGTTTGATCMTGGCTCAG-3') và $1492 \mathrm{mR}$ (5'GGYTACCTTGTTACGACTT-3') với chương trình PCR $95^{\circ} \mathrm{C}-5$ phút, 30 chu kỳ tiếp theo $\left(95^{\circ} \mathrm{C}-30\right.$ giây; $55^{\circ} \mathrm{C}-40$ giây; $72^{\circ} \mathrm{C}-90$ giây) và $72^{\circ} \mathrm{C}-5$ phút bởi phòng thí nghiệm Công nghệ động vật, trường Đại học Konkuk, Hàn Quốc [14]. Kết quả giải trình tự được so sánh với cơ sở dữ liệu 16S-rRNA của xạ khuẩn có sẵn trên National Center for Biotechnology Information (NCBI) bằng công cụ BLASTN (https://blast.ncbi.nlm.nih.gov/Blast.cgi)

\subsection{Chuẩn bị dung dịch xạ khuẩn để ứng dụng xử lý nước thải giàu tinh bột}

Các chủng xạ khuẩn được tuyển chọn có hoạt tính sinh amylase cao được nuôi cấy trên môi trường lỏng Gause I ở $37^{\circ} \mathrm{C}$ sau 7 ngày, thu nhận dịch tăng sinh và cấy $3 \mathrm{ml}$ dung dịch tăng sinh của các chủng xạ khuẩn vào $50 \mathrm{ml}$ môi trường lỏng Gause II (cao thịt $3,0 \mathrm{~g}$, pepton $5,0 \mathrm{~g}, \mathrm{NaCl} 5,0 \mathrm{~g}$, glucose $10,0 \mathrm{~g}$, nước cất đủ $1000 \mathrm{ml}, \mathrm{pH} 7,2-7,4)$ nuôi tăng sinh trong 7 ngày ở $37^{\circ} \mathrm{C}$, lắc 150 vòng/phút. Dịch xạ khuẩn tăng sinh này được sử dụng như chế phẩm xạ khuẩn cho các thí nghiệm xử lý nước thải sản xuất bún tiếp theo. 


\section{5. Ứng dụng xạ khuẩn xử lý nước thải giàu tinh bột}

Nước thải giàu tinh bột được thu nhận từ các cơ sở sản xuất bún tại tỉnh Tiền Giang và đồng nhất thành hỗn hợp nước thải sử dụng trong thí nghiệm tiếp theo. Chế phẩm xạ khuẩn được phối trộn với nước thải theo các tỉ lệ khác nhau (tt/tt) lần lượt là $0 \%, 0,5 \%, 1,0 \%, 2,0 \%$. Các hỗn hợp nước thải được ủ ở nhiệt độ phòng, lắc 150 vòng/phút trong thời gian 10 ngày. Các chỉ tiêu cơ bản tiêu biểu của nước thải như $\mathrm{BOD}_{5}, \mathrm{COD}$, $\mathrm{pH}$, sự thay đổi hàm lượng tinh bột tương đối được kiểm tra trước và sau khi xử lý với chế phẩm xạ khuẩn. Ngoài ra, chất lượng của nước thải sau khi xử lý với chế phẩm xạ khuẩn cũng được kiểm tra trên sự phát triển của hạt đậu xanh với các nghiệm thức được tưới nước thải sau xử lý ở tỷ lệ khác nhau trong 3 ngày.

\subsection{Phương pháp xác định $\mathrm{BOD}_{5}$ và $\mathrm{COD}$ trong nước thải bún}

Hàm lượng $\mathrm{BOD}_{5}$ và $\mathrm{COD}$ là các chỉ tiêu thể hiện các nhu cầu oxy sinh học và oxy hóa học cần thiết để oxy hóa lượng chất hữu cơ hòa tan trong nước thải. Các giá trị $\mathrm{BOD}_{5}$ và $\mathrm{COD}$ sẽ cho thấy sự ô nhiễm các chất hữu cơ có trong chất thải cao và việc kiểm tra các chỉ tiêu $\mathrm{BOD}_{5}$ và $\mathrm{COD}$ là tiêu chí cho việc đánh giá chất lượng của nước thải. Mẫu nước thải cần phân tích được xử lý sơ bộ và pha loãng với những lượng khác nhau của một loại nước loãng giàu oxy hòa tan và chứa các vi sinh vật hiếu khí, có ức chế sự nitrat hóa, ủ mẫu ở nhiệt độ $20^{\circ} \mathrm{C}$ trong thời gian xác định là 5 ngày, ở chỗ tối, trong bình đầy và nút kín. Nồng độ oxy hòa tan trước và sau khi ủ được xác định bằng phương pháp quy định trong TCVN 6001-1:2000 và ghi nhận hàm lượng $\mathrm{BOD}_{5}$ có trong nước thải [15]. Hàm lượng $\mathrm{COD}$ được xác định bằng cách đun hồi lưu mẫu với lượng potassium dichromate đã biết trước khi có mặt thuỷ ngân (II) sunfate và xúc tác bạc trong axit sunfuric đặc trong khoảng thời gian nhất định, trong quá trình đó một phần dichromate bị khử do sự có mặt các chất có khả năng bị oxi hoá. Lượng dichromate còn lại được chuẩn độ với sắt (II) amoni sunfate. Giá trị $\mathrm{COD}$ được tính toán từ lượng dichromat bị khử, 1 mol dichromate $\left(\mathrm{Cr}_{2} \mathrm{O}_{7}{ }^{2-}\right)$ tương đương với 1,5 mol oxy $\left(\mathrm{O}_{2}\right)$ [16]. Các mẫu được hỗ trợ phân tích bởi công ty Cổ phần Kỹ thuật Tiêu chuẩn QCVN Việt Nam (537/7 Nguyễn Oanh, phường 17, quận Gò Vấp, Tp. Hồ Chí Minh).

\section{7. Đánh giá sự thay đổi hàm lượng tinh bột tương đối có trong nước thải sản xuất bún}

Hàm lượng tinh bột tương đối có trong nước thải giàu tinh bột được xác định dựa trên cơ sở của phản ứng tạo màu giữa tinh bột và dung dịch lugol. Dung dịch lugol được chuẩn bị bằng cách cân $2,0 \mathrm{~g} \mathrm{KI}$ - nồng độ $\mathrm{I}_{2} 0,2 \%$, thêm nước cất vừa đủ để tạo thành dung dịch bão hòa, thêm tiếp $0,2 \mathrm{~g} \mathrm{I}_{2} ;$ khi lượng $\mathrm{I}_{2}$ đã tan hết, chuyển toàn bộ sang bình định mức $100 \mathrm{ml}$ và thêm nước cất đến vạch mức và lắc đều. Dung dịch được chuẩn bị chỉ sử dụng trong ngày và bảo quản trong lọ nâu, tránh ánh sáng. Dung dịch tinh bột được đun chín với hàm lượng tinh bột đã được xác định trước, thêm vào một thể tích dung dịch lugol theo tỷ lệ 5:1 về thể tích sao cho phản ứng xuất hiện phức màu xanh tím đặc trưng. Từ đó, dựng đồ thị tương quan giữa hàm lượng tinh bột và độ hấp phụ màu ở bước sóng $580 \mathrm{~nm}$. Theo cách này, nước thải bún cũng được cho vào một lượng dung dịch lugol nhất định theo thể tích là 5:1, tiến hành đo $\mathrm{OD}_{580 \mathrm{~nm}}$ của hỗn hợp trên, dựa vào đường chuẩn, xác định được sự thay đổi về hàm lượng tinh bột tương đối có trong nước thải giàu tinh bột trước và sau khi xử lý với chế phẩm xạ khuẩn [17].

\section{8. Đánh giá chất lượng của nước thải bún sau khi xử lý bằng chế phẩm xạ khuẩn lên sự phát triển của hạt đậu xanh}

Hạt đậu xanh được ngâm với nước ấm trong vòng 8-12 giờ cho nảy mầm, chuẩn bị ly nhựa, có lót sẵn một lớp khăn giấy thấm ở đáy ly và đáy ly có lỗ thoát nước. Các hạt đã nảy mầm được phân chia vào các ly nhựa này, mỗi ly chứa khoảng 10-20 hạt. Nước thải chưa xử lý và nước thải được xử lý với chế phẩm xạ khuẩn ở các tỉ lệ khác nhau được dùng để tưới và quan sát sự phát triển của hạt đậu xanh. Thay thế nước thải sản xuất bún bằng nước cất để làm mẫu đối chứng. Hạt đậu xanh ủ trong các ly nhựa được đặt trong tối và tưới ướt liên tục trong vòng 3 ngày, mỗi ngày 3-4 lần để cung cấp đủ độ ẩm cho hạt phát triển. Sau đó, quan sát các đặc điểm của sự nảy mầm hạt đậu xanh, đối chiếu với mẫu đối chứng bằng nước cất [1].

\subsection{Phương pháp thống kê và xử lý số liệu}

Giá trị kết quả của các thí nghiệm là trung bình của 3 lần lặp lại. Số liệu được tính toán, vẽ biểu đồ trên Microsoft Excel 2013 và được xử lý thống kê bằng phương pháp ANOVA bằng phần mềm Statgraphics Centurion 18.

\section{KẾT QUẢ VÀ THẢO LUẬN}

\subsection{Phân lập và thuần khiết các chủng xạ khuẩn}


Từ nhiều mẫu đất khác nhau, chúng tôi đã phân lập và thuần khiết được 20 chủng xạ khuẩn. Các chủng này được quan sát đặc điểm hình thái trên môi trường thạch Gause I sau khi ủ 7 ngày ở $37^{\circ} \mathrm{C}$. Dựa vào sự khác nhau về hình dạng khuẩn lạc, màu sắc khuẩn ty và sắc tố khuếch tán trên môi trường thạch nuôi cấy Gause I, các chủng xạ khuẩn phân lập được kí hiệu lần lượt là RBXK2, RBXK3, RBXK4, RBXK5, RBXK7, RBXK8, RBXK9, RBXK10, RBXK16, RBXK17, RBXK21, RBXK22, RBXK23, VTXK10, VTXK11, VTXK17, VTXK19, VTXK20, VTXK21, VTXK22 và được thể hiện trong bảng 1 và hình 1.

Bảng 1. Đặc điểm hình thái đại thể của các chủng xạ khuẩn phân lập được trên môi trường Gause I.

\begin{tabular}{|c|c|c|c|c|c|}
\hline STT & $\begin{array}{c}\text { Tên Xạ } \\
\text { khuân }\end{array}$ & $\begin{array}{c}\text { Kích thước } \\
\text { khuấn lạc } \\
(\mathrm{mm})\end{array}$ & $\begin{array}{c}\text { Khuẩn ty sinh } \\
\text { dưỡng }\end{array}$ & $\begin{array}{c}\text { Khuẩn ty khí } \\
\text { sinh }\end{array}$ & Sắc tố tiết \\
\hline 1 & RBXK2 & $2,0 \pm 0,16$ & Trắng vàng & Vàng nhạt & Không \\
\hline 2 & RBXK3 & $2,0 \pm 0,41$ & Nâu & Vàng nâu & Nâu \\
\hline 3 & RBXK4 & $6,0 \pm 0,82$ & Đỏ tím & Đỏ tím & Đỏ tím \\
\hline 4 & RBXK5 & $1,0 \pm 0,0$ & Trắng đục & Trắng đục & Không \\
\hline 5 & RBXK7 & $3,0 \pm 0,41$ & Trắng đục & Trắng đục & Không \\
\hline 6 & RBXK8 & $0,93 \pm 0,09$ & Nâu nhạt & Nâu đen & Nâu \\
\hline 7 & RBXK9 & $2,0 \pm 0,24$ & Nâu nhạt & Trắng nà & Nâu nhạt \\
\hline 8 & RBXK10 & $1,0 \pm 0,0$ & Trắng nà & Trắng & Không \\
\hline 9 & RBXK16 & $4,0 \pm 0,82$ & Trắng trong & Trắng đục & Không \\
\hline 10 & RBXK17 & $2,07 \pm 0,09$ & Trắng trong & Vàng cam & Không \\
\hline 11 & RBXK21 & $2,0 \pm 0,82$ & Vàng cam & Trắng & Không \\
\hline 12 & RBXK22 & $1,0 \pm 0,0$ & Trắng đục & Trắng đục & Không \\
\hline 13 & RBXK23 & $1,0 \pm 0,0$ & Nâu nhạt & Nâu đậm & Nâu \\
\hline 14 & VTXK10 & $1,0 \pm 0,0$ & Cam & Trắng & Vàng nhạt \\
\hline 15 & VTXK11 & $1,0 \pm 0,0$ & Trắng & Trắng & Trắng \\
\hline 16 & VTXK17 & $2,07 \pm 0,09$ & Vàng nhạt & Trắng & Không \\
\hline 17 & VTXK19 & $2,0 \pm 0,82$ & Trắng vàng & Trắng & Nâu nhạt \\
\hline 18 & VTXK20 & $2,0 \pm 0,0$ & Vàng & Vàng nâu & Không \\
\hline 19 & VTXK21 & $2,33 \pm 0,85$ & Trắng & Trắng & Không \\
\hline 20 & VTXK22 & $3,0 \pm 0,82$ & Vàng nhạt & Trắng & Nâu vàng \\
\hline
\end{tabular}

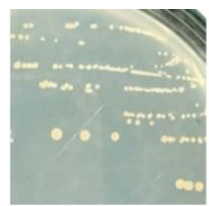

RBXK2

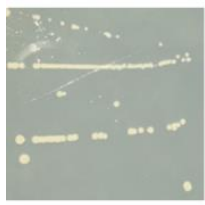

RBXK10

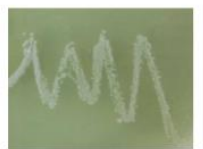

VTXK10

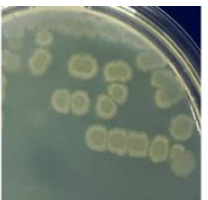

RBXK3

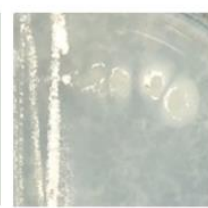

RBXK16

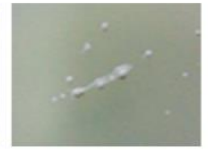

VTXK11

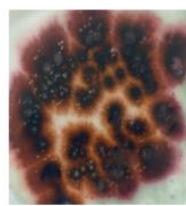

RBXK4

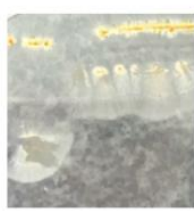

RBXK17

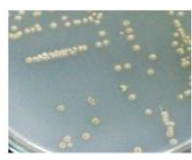

VTXK17

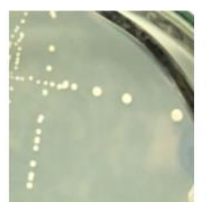

RBXK5

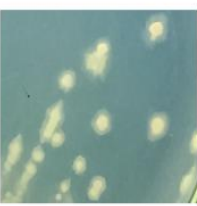

RBXK21

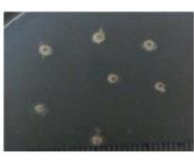

VTXK19

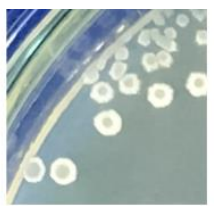

RBXK7

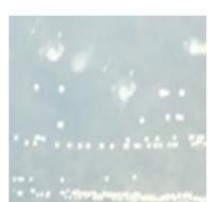

RBXK22

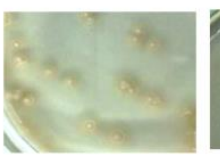

VTXK20

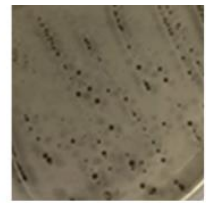

RBXK8

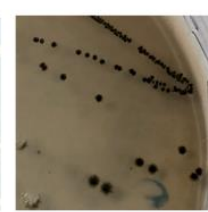

RBXK23

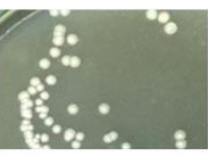

VTXK21

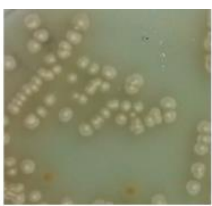

RBXK9

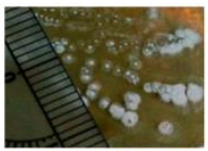

VTXK22

Hình 1: Hình thái khác nhau của các chủng xạ khuẩn trên môi trường Gause $\mathrm{I}$. 


\subsection{Tuyển chọn xạ khuẩn có khả năng sinh enzyme amylase ngoại bào}

Các chủng xạ khuẩn sau khi được phân lập sẽ tiến hành khảo sát khả năng sản sinh amylase ngoại bào dựa trên sự phân hủy cơ chất là tinh bột và được nhận diện bằng thuốc thử lugol. Căn cứ vào vòng phân giải tinh bột và đường kính khuẩn lạc, hoạt tính amylase của các chủng xạ khuẩn được xác định sơ bộ và thể hiện trong hình 2 và bảng 2 .

Bảng 2. Hoạt tính enzyme của các chủng xạ khuẩn sau 10 ngày nuôi cấy

\begin{tabular}{|c|c|}
\hline Xạ khuẩn & Độ lớn vòng phân giải tinh bột $\mathbf{( m m )}$ \\
\hline RBXK2 & $23,0 \pm 0,2$ \\
\hline RBXK3 & $35,0 \pm 0,2$ \\
\hline RBXK7 & $17,0 \pm 0,3$ \\
\hline RBXK16 & $26,0 \pm 0,3$ \\
\hline RBXK17 & $21,0 \pm 0,3$ \\
\hline RBXK23 & $10,0 \pm 0,2$ \\
\hline VTXK10 & $11,0 \pm 0,3$ \\
\hline VTXK11 & $5,0 \pm 0,1$ \\
\hline VTXK17 & $4,0 \pm 0,1$ \\
\hline VTXK20 & $11,0 \pm 0,1$ \\
\hline
\end{tabular}

Trong số 20 chủng xạ khuẩn phân lập được và được kiểm tra sơ bộ hoạt tính amylase, 10 chủng xạ khuẩn đã thể hiện khả năng phân giải tinh bột ở các mức độ mạnh yếu khác nhau. Các chủng xạ khuẩn RBXK2, RBXK3, RBXK16, RBXK17 thể hiện hoạt tính amylase mạnh mẽ với đường kính vòng phân giải từ $21,0 \pm 0,3 \mathrm{~mm}$ đến $35,0 \pm 0,2 \mathrm{~mm}$, trong đó chủng RBXK3 thể hiện hoạt tính amylase mạnh nhất với đường kính vòng phân giải lên đến $35,0 \pm 0,2 \mathrm{~mm}$. Hoạt tính amylase yếu nhất được quan sát thấy ở 2 chủng xạ khuẩn VTXK11 và VTXK17 với đường kính vòng phân giải lần lượt là $5,0 \pm 0,1 \mathrm{~mm}$ và $4,0 \pm 0,1 \mathrm{~mm}$. Các chủng xạ khuẩn RBXK7, RBXK23, VTXK10, VTXK20 thể hiện hoạt tính amylase trung bình với vòng phân giải tinh bột trong khoảng $10,0 \pm 0,2 \mathrm{~mm}$ đến $17,0 \pm 0,3 \mathrm{~mm}$. Với độ lớn vòng phân giải 4,0-35,0 mm, 10 chủng xạ khuẩn phân lập được thể hiện khả năng sản sinh amylase ngoại bào cao hơn 8 chủng Streptomyces S1-S8 được phân lập và chọn lọc từ biển trong nghiên cứu của Sathya Rengasamy và cộng sự (2018) với vòng phân giải tinh bột được ghi nhận trong khoảng 4,0-20,0 mm [13], đồng thời so sánh độ lớn vòng phân giải với chủng Streptomyces sp. SLBA-08 được chọn lọc từ 286 chủng xạ khuẩn trong nghiên cứu của Santos và cộng sự (2012) thì chủng xạ khuẩn RBXK3 trong nghiên cứu này có kết quả vòng phân giải tinh bột tương đương [18]. Căn cứ vào kết quả về khả năng sản sinh amylase, các chủng xạ khuẩn có hoạt tính amylase được tuyển chọn để thử nghiệm sản xuất chế phẩm phục vụ cho việc xử lý nước thải giàu tinh bột.

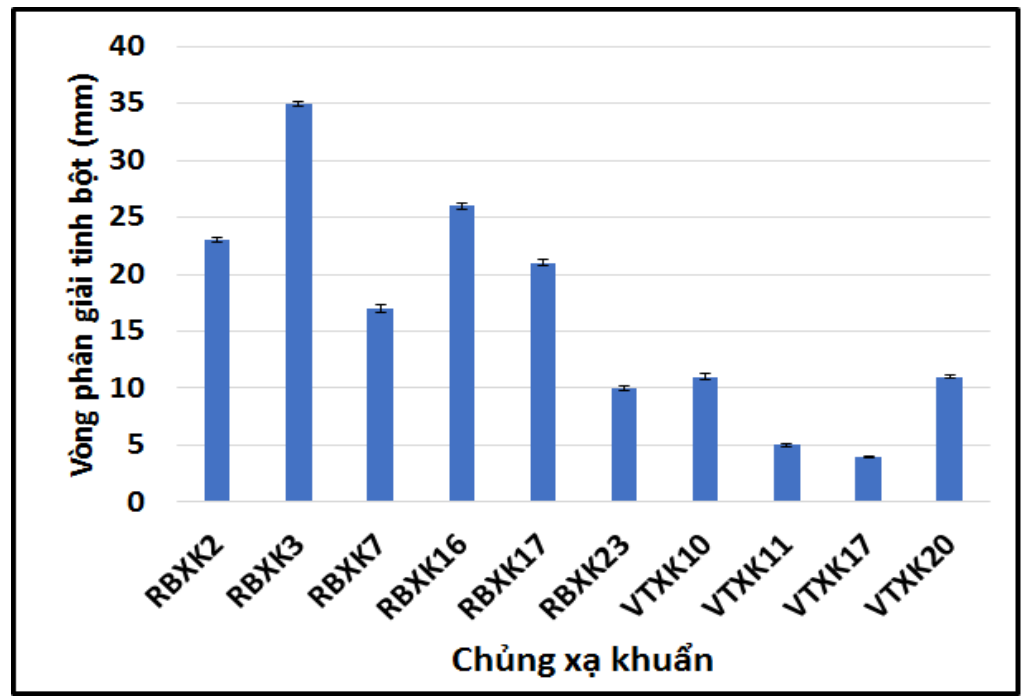

Hình 2. Hoạt tính amylase của các chủng xạ khuẩn dựa trên vòng phân giải tinh bột 
Hình thái vi thể của các chủng xạ khuẩn được chọn cũng được tiến hành quan sát trên tiêu bản phòng ẩm bằng kính hiển vi quang học. Kết quả quan sát cho thấy cuống sinh bào tử của các chủng xạ khuẩn VTXK10, VTXK11, VTXK20 có dạng gấp khúc, phân nhánh trong khi cuống sinh bào tử của các chủng xạ khuẩn RBXK2, RBXK3, RBXK7, RBXK16, VTXK17, RBXK17, RBXK23 có dạng xoắn, với 2-5 vòng xoắn. Các chủng xạ khuẩn được tiến hành định danh bằng phương pháp sinh học phân tử với việc giải trình tự vùng $16 \mathrm{~S}$ rRNA. Kết quả ban đầu xác định được chủng VTXK10 và VTXK11 có độ tương đồng cao tương ứng với Amycolaptosis sp. CD-15 và Amycolaptosis sp. CD-17 là 99,35\% và 98,28\%, đồng thời chủng RBXK3 có độ tương đồng với Streptomyces canus với hệ số tương đồng 99\%.

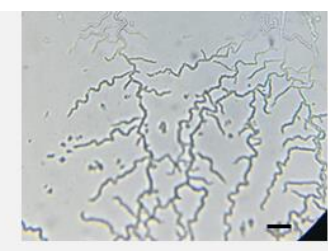

RBXK2

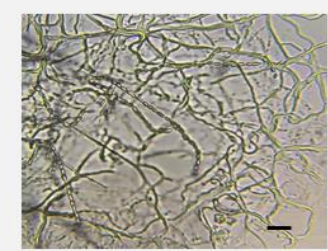

RBXK23

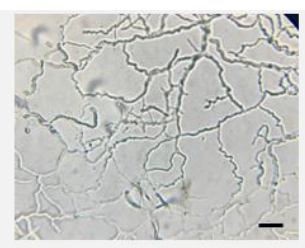

RBXK3

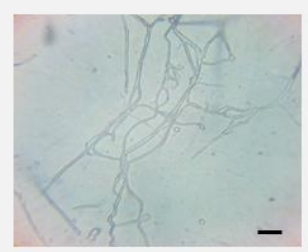

VTXK10

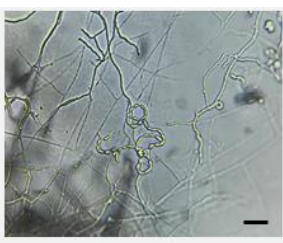

RBXK7

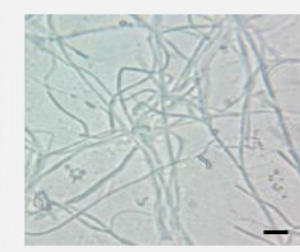

VTXK11

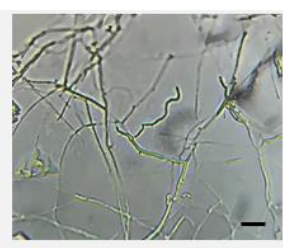

RBXK16

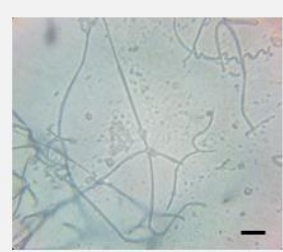

VTXK17

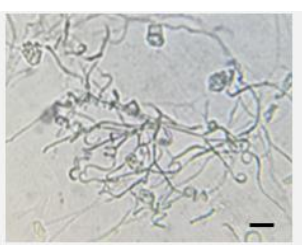

RBXK17

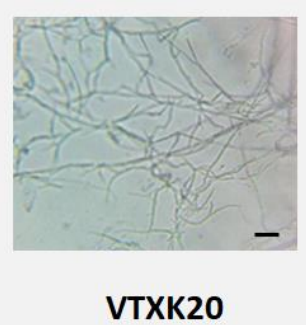

Hình 3. Hình thái vi thể của các chủng xạ khuẩn ở độ phóng đại X1000 (bar 0,02mm)

\section{3. Ứng dụng xạ khuẩn xử lý nước thải giàu tinh bột}

Từ các kết quả khảo sát sơ bộ khả năng sinh enzyme amylase, các chủng xạ khuẩn có khả năng sinh amylase được nuôi tăng sinh trong môi trường Gause II ở nhiệt độ phòng trong 7 ngày. Kiểm tra mật độ tế bào xạ khuẩn bằng phương pháp đếm khuẩn lạc. Dung dịch nuôi cấy xạ khuẩn được sử dụng làm chế phẩm để ứng dụng xử lý nước thải giàu tinh bột có mật độ 5 x $10^{7} \mathrm{CFU} / \mathrm{ml}$.

Mẫu nước thải giàu tinh bột được bổ sung chế phẩm xạ khuẩn theo các tỷ lệ khác nhau $(0,5 \%, 1,0 \%, 2,0 \%)$. Mẫu nước thải ban đầu không bổ sung chế phâm xạ khuẩn được sử dụng như nghiệm thức đối chứng. Các thử nghiệm được tiến hành ủ tại nhiệt độ phòng, lắc 150 vòng/phút trong 10 ngày. Các chỉ tiêu $\mathrm{BOD}_{5}, \mathrm{COD}$, hàm lượng tinh bột sau xử lý, giá trị pH được kiểm tra và được thể hiện trong bảng 3.

Bảng 3: Giá trị $\mathrm{BOD}_{5}, \mathrm{COD}$, tinh bột, $\mathrm{pH}$ của nước thải giàu tinh bột sau khi được xử lý với chế phẩm xạ khuẩn.

\begin{tabular}{|c|c|c|c|c|}
\hline $\begin{array}{c}\text { Tỷ lệ chế phẩm xạ } \\
\text { khuâ̂n }(\%)\end{array}$ & $\mathrm{BOD}_{5}(\mathrm{mg} / \mathrm{l})$ & $\mathrm{COD}(\mathrm{mg} / \mathrm{l})$ & $\begin{array}{c}\text { Hàm lượng tinh } \\
\text { bột tương đối } \\
(\mathrm{mg} / \mathrm{l})\end{array}$ & Giá trị $\mathrm{pH}$ \\
\hline Control & $5600^{\mathrm{a}} \pm 163$ & $18720^{\mathrm{ab}} \pm 216$ & $32,3^{\mathrm{ac}} \pm 2,7$ & $3,2^{\mathrm{ad}} \pm 0,6$ \\
\hline $0,5 \%$ & $2150^{\mathrm{b}} \pm 204$ & $9544^{\mathrm{bb}} \pm 283$ & $22,2^{\mathrm{bc}} \pm 3,1$ & $6,0^{\mathrm{bd}} \pm 0,5$ \\
\hline $1,0 \%$ & $2210^{\mathrm{b}} \pm 82$ & $8640^{\mathrm{cb}} \pm 283$ & $20,7^{\mathrm{bc}} \pm 3,0$ & $6,7^{\mathrm{bd}} \pm 0,7$ \\
\hline $2,0 \%$ & $2010^{\mathrm{b}} \pm 82$ & $9600^{\mathrm{bb}} \pm 82$ & $19,9^{\mathrm{bc}} \pm 3,2$ & $6,9^{\mathrm{bd}} \pm 0,8$ \\
\hline
\end{tabular}

Sau thời gian xử lý với chế phẩm xạ khuẩn, kết quả cho thấy các giá trị $\mathrm{BOD}_{5}, \mathrm{COD}$, tinh bột giảm mạnh. Giá trị $\mathrm{BOD}_{5}$ giảm 61,6-65,1\%, giá trị $\mathrm{COD}$ giảm 48,7-53,8\%, hàm lượng tinh bột tương đối được cho thấy giảm 31,1-38,4\% sau khi được xử lý với chế phẩm xạ khuẩn ở các tỷ lệ khác nhau. Sự thay đổi các giá trị không có khác biệt nhiều khi xử lý nước thải giàu tinh bột với tỷ lệ chế phẩm xạ khuẩn $0,5 \%, 1,0 \%, 2,0 \%$. Các chỉ tiêu $\mathrm{BOD}_{5}, \mathrm{COD}$ giảm đã thể hiện các nhu cầu oxy sinh học và oxy hóa học cần thiết để oxy hóa lượng chất hữu cơ hòa tan trong nước thải giàu tinh bột giảm, điều này cho thấy chế phẩm xạ khuẩn có hoạt tính amylase cao đã tham gia mạnh mẽ vào việc chuyển hóa các chất hữu cơ có trong nước thải này, tương 
tự như trong nghiên cứu sử dụng các chủng xạ khuẩn Streptomyces indiaensis ACT 7 và Streptomyces hygroscopicus $\mathrm{ACT} 14$ để xử lý nước thải từ nhà máy sữa với việc giảm các giá trị $\mathrm{BOD}_{5}$ và $\mathrm{COD}$ tương ứng là 56,37-59,95\% và 51,53\% 55,32\% sau 10 ngày xử lý [1] và thấp hơn trong nghiên cứu xử lý nước thải bằng xạ khuẩn của Wael $\mathrm{N}$. Hozzein và cộng sự (2012) với việc giảm các giá trị $\mathrm{BOD}_{5}$ và $\mathrm{COD}$ tương ứng là 68,1-95,4\% và 47,7-84,7\% [4], cũng như trong nghiên cứu của More và cộng sự (2001) với sự giảm COD 70-80\% [19]. Ngoài ra, giá trị $\mathrm{pH}$ của nước thải ban đầu từ 3,2 đã dần điều chỉnh và tăng về mức acid yếu $(\mathrm{pH}$ 6,0) và gần trung tính $(\mathrm{pH} 6,9)$ khi được xử lý với các tỷ lệ chế phẩm xạ khuẩn khác nhau. Sự điều chỉnh giá trị $\mathrm{pH}$ về mức cần bằng cũng được ghi nhận trong nghiên cứu sử dụng chủng xạ khuẩn để xử lý nước thải của Amany $\mathrm{G}$. Madkour và cộng sự (2019) với giá trị $\mathrm{pH}$ được điều chỉnh từ $\mathrm{pH} 9,32$ thành $\mathrm{pH}$ 8,283 [11]. Bên cạnh đó, kết quả hàm lượng tinh bột tương đối trong nước thải giảm cũng chứng minh được khả năng chuyển hóa hợp chất hữu cơ này để phục vụ cho sự sinh trưởng và phát triển của xạ khuẩn, giảm thiểu các chất hữu cơ gây ô nhiễm trong nước thải. Ngoài ra, kết quả phân tích thống kê cho thấy không có sự khác biệt đáng kể giữa các nghiệm thức bổ sung tỉ lệ chế phẩm xạ khuẩn khác nhau $(0,5 \%-2,0 \%)$ (ANOVA, $\mathrm{n}=3$, độ tin cậy $95 \%$ ) lên sự thay đổi các giá trị $\mathrm{BOD}_{5}$, tinh bột và $\mathrm{pH}$ của nước thải sau xử lý. Do đó, với các kết quả thu nhận được đã cho thấy hiệu quả tích cực của đối tượng vi sinh vật này trong việc xử lý nước thải giàu tinh bột.

A

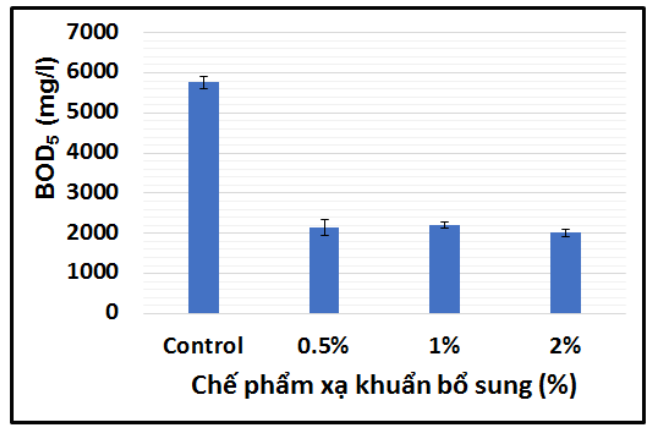

C

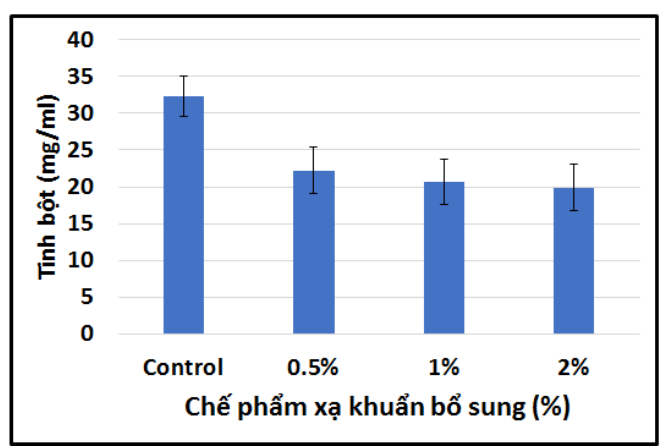

B

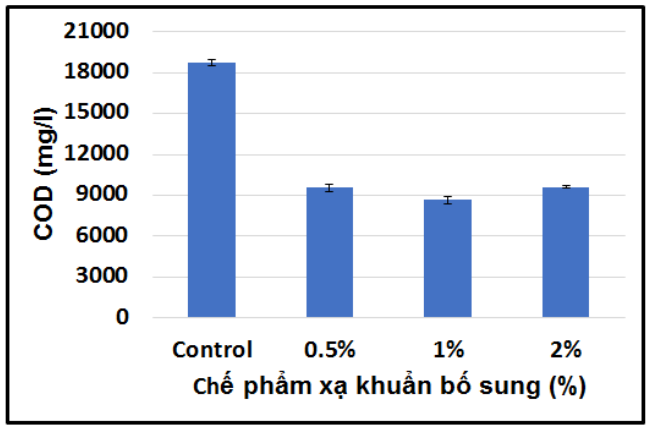

D

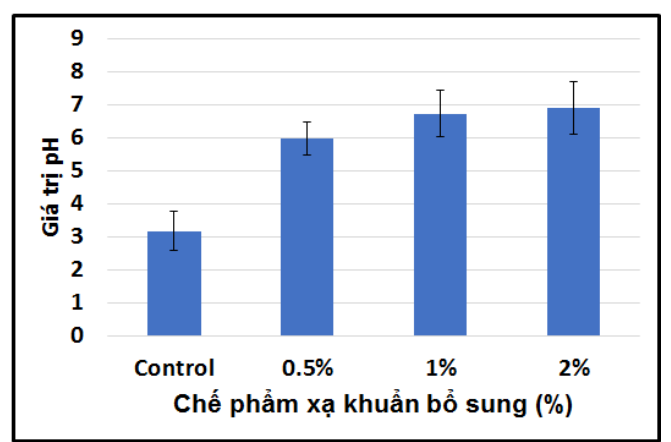

Hình 4. Các chỉ tiêu của nước thải giàu tinh bột sau khi được xử lý với chế phẩm xạ khuẩn. (A) Chỉ tiêu $\mathrm{BOD}_{5}$ tại $20^{\circ} \mathrm{C}$; (B) Chỉ tiêu COD tại $20^{\circ} \mathrm{C}$; (C) Sự thay đổi của hàm lượng tinh bột và (D) Sự thay đổi của giá trị pH sau khi xử lý bằng chế phẩm xạ khuẩn.

\subsection{Tác động của nước thải giàu tinh bột được xử lý với chế phẩm xạ khuẩn lên sự phát triển của hạt đậu xanh}

Nước thải từ nhiều nguồn khác nhau sẽ được thải ra môi trường, thấm vào đất, mạch nước ngầm, vào các ao, hồ, sông, suối và sẽ ảnh hưởng lớn đến sự sinh trưởng và phát triển của nhiều loài sinh vật khác. Để đánh giá hiệu quả xử lý nước thải giàu tinh bột của chế phẩm xạ khuẩn, chúng tôi tiến hành nuôi ủ các hạt đậu xanh và quan sát sự phát triển của chúng khi được tưới bằng nước thải không xử lý, nước thải xử lý với các tỷ lệ chế phẩm xạ khuẩn khác nhau $0,5 \%, 1,0 \%, 2,0 \%$, mẫu được tưới bằng nước cất là nghiệm thức đối chứng dương. Sau 3 ngày nuôi ủ, kết quả phát triển của các hạt đậu xanh được quan sát thấy như được thể hiện ở hình 6 . 


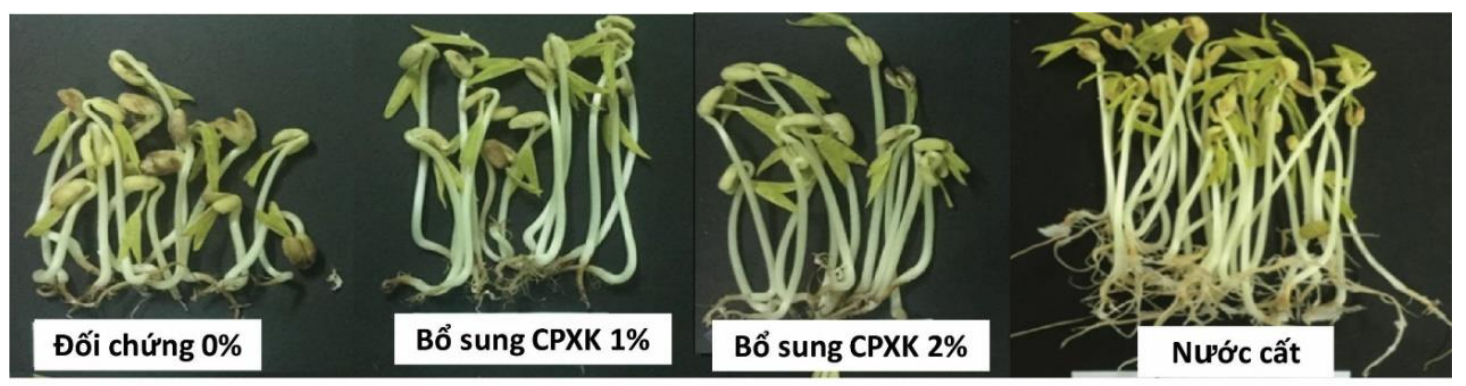

Hình 5. Đặc điểm phát triển của hạt đậu xanh được tưới bằng nước thải sản xuất bún sau khi xử lý với chế phẩm xạ khuẩn.

Kết quả quan sát sự phát triển của những hạt đậu xanh được tưới với nước thải xử lý chế phẩm xạ khuẩn cho kết quả tốt hơn một cách rõ rệt khi không xử lý với xạ khuẩn. Sự phát triển của các hạt đậu xanh khi được tưới với nước thải không xử lý với chế phẩm xạ khuẩn với thân ngắn, cong, rễ ngắn, phần lớn lá mầm bị nhiễm khuẩn, thối nhũn. Quan sát sự phát triển của các hạt đậu xanh khi được tưới với nước thải xử lý với chế phẩm xạ khuẩn ở tỷ lệ $1,0 \%$ và $2,0 \%$ cho thấy thân cây dài xấp xỉ mẫu đối chứng $(75 \%-100 \%$ chiều dài thân so với đối chứng), sự nhiễm khuẩn và thối nhũn trên bề mặt lá mầm giảm đáng kể với số lượng và diện tích thối nhũn trên bề mặt giảm (1 cây/13 cây bị thối nhũn). Mặc dù sự phát triển của các hạt đậu xanh không hoàn toàn tương tự như đối chứng nhưng kết quả xác nhận được hiệu quả xử lý nước thải giàu tinh bột của chế phẩm xạ khuẩn. Việc sản sinh ra các chất trao đổi thứ cấp có khả năng ức chế sự phát triển vi khuẩn của xạ khuẩn đã được quan sát thấy trong nhiều nghiên cứu khác nhau, cũng như ứng dụng sản xuất kháng sinh từ xạ khuẩn, do đó sự giảm thiểu các hiện tượng nhiễm khuẩn cũng như sự thối nhũn trên bề mặt của lá mầm đã khẳng định hoạt động hiệu quả của các xạ khuẩn trong chế phẩm xử lý nước thải giàu tinh bột [6-8].

\section{KẾT LUẬN}

Xạ khuẩn có nhiều hoạt tính sinh học và được ứng dụng trong nhiều lĩnh vực khác nhau. Việc ứng dụng xạ khuẩn trong các chế phẩm xử lý mồi trường đã được quan tâm và triển khai rộng rãi. Các chủng xạ khuẩn phân lập được từ nhiều nguồn khác nhau và được chọn lọc trên cơ sở hoạt tính phân giải tinh bột cao. 10 chủng xạ khuẩn đã được chọn lọc và tiến hành thử nghiệm xử lý với nước thải giàu tinh bột. Kết quả cho thấy nước thải ở các nghiệm thức được xử lý với chế phẩm xạ khuẩn đã giảm các chỉ số $\mathrm{BOD}_{5}(61,6-65,1 \%)$, $\operatorname{COD}(48,7-53,8 \%)$, hàm lượng tinh bột tương đối $(31,1-38,4 \%)$ và giá trị $\mathrm{pH}$ được cân bằng về gần trung tính $(6,0-6,9)$ khi thử nghiệm với chế phẩm xạ khuẩn ở các tỷ lệ $0,5 \%, 1,0 \%, 2,0 \%$. Ngoài ra, kết quả khảo sát ảnh hưởng của nước thải sau xử lý bằng xạ khuẩn lên sự phát triển của hạt đậu xanh cũng khẳng định thêm tiềm năng ứng dụng của loại vi sinh vật này. Sự phát triển của hạt đậu xanh trong thử nghiệm được tưới bằng nước thải có xử lý với chế phẩm xạ khuẩn tương tự với nghiệm thức đối chứng khi hạt đậu xanh được tưới bằng nước cất, và có khác biệt đáng kể với nghiệm thức được tưới bằng nước thải không xử lý. Như vậy, việc sử dụng xạ khuẩn hay các yếu tố sinh học trong xử lý nước thải, giúp giảm thiểu việc sử dụng các hóa chất trong xử lý môi trường, góp phần tạo nên môi trường sống bền vững.

\section{LỜI CẢM ƠN:}

Kết quả nghiên cứu này là một phần trong đề tài nghiên cứu khoa học cấp trường "Tuyển chọn xạ khuẩn và phân tích đặc tính của hệ enzyme amylase ngoại bào từ xạ khuẩn", mã số 184.TP13, được hỗ trợ kinh phí từ trường Đại học Công nghiệp thành phố Hồ Chí Minh. Do đó, chúng tôi xin chân thành cảm ơn trường Đại học Công nghiệp thành phố Hồ Chí Minh đã hỗ trợ cho các thí nghiệm trong đề tài nghiên cứu khoa học này.

\section{TÀI LIỆU THAM KHẢO}

1. B. Sathy Priya, T. Stalin and K. Selvam, Ecosafe bioremediation of dairy industry effluent using Streptomyces indiaensis ACT 7 and Streptomyces hygroscopicus ACT 14 and application for seed germination of Vigna radiata. African Journal of Microbiology Research, 2014. 8(23): p. 2286-2289.

2. Majdah Mohamed, A.A., Bioremediation of toxic heavy metals by waste water actinomycetes. International Journal of Current Research, 2016. 8(1): p. 24870-24875. 
3. Katja Bunzel, M.K., Matthias Liessc, Effects of organic pollutants from wastewater treatment plants on aquatic invertebrate communities. Water Research, 2013. 47(2): p. 597-606.

4. Wael, N.H., Efficiency of some actinomycete isolates in biological treatment and removal of heavy metals from wastewater. African Journal of Biotechnology, 2012. 11(5): p. 1163-1168.

5. Bo Zhang, Xiangyang Xu and Liang Zhu., Activated sludge bacterial communities of typical wastewater treatment plants: distinct genera identifcation and metabolic potential diferential analysis. AMB Express, 2018. 8(184): p. 1-14.

6. Kamjam M, S.P., Deng Z, Hong K, Deep Sea Actinomycetes and Their Secondary Metabolites. Frontier in Microbiology, 2017. 8: p. 760-769

7. Bull AT, S.J., Ward AC, Goodfellow M., Marine actinobacteria; perspectives, challenges, future directions. Antonie Van Leeuwehoek, 2005. 87: p. 65-79.

8. Sreejetha M, D., Veena S, Kokati Venkata BR., The bioactive potential of Streptomyces variabilisDV-35 isolated from Thottada Marine sediments, Kannur, Kerala. Asian Journal of Pharmaceutical and Clinical Research, 2016. 9(9): p. 67-71.

9. Khamna, S., A. Yokota, and S. Lumyong, Actinomycetes isolated from medicinal plant rhizosphere soils: diversity and screening of antifungal compounds, indole-3-acetic acid and siderophore production. World Journal of Microbiology and Biotechnology, 2008. 25(4): p. 649-655.

10. Salma Mukhtar, A.Z., Dalaq Aiysha, Kauser Abdulla Malik and Samina Mehnaz, Actinomycetes: A Source of Industrially Important Enzymes. Journal of Proteomics \& Bioinformatics, 2017. 10(12): p. 316-319.

11. Amany G. Madkour, Moaz M. Hamed and Mahmoud A. Dar, Removal of ammonia and orthophosphate from domestic wastewater using marine actinomycetes. Egyptian Journal of Aquatic Biology \& Fisheries, 2019. 23(3): p. 455 - 465.

12. Parichat Saenna, T.G., Nuttapol Onpan and Watanalai Panbangred, Actinomycetes community from starch factory wastewater. Research Journal of Microbiology, 2011. 6(6): p. 534-542.

13. Sathya Rengasamy Ut: Isolation, screening and determination of a-amylase activity from marine Streptomyces species. International Journal of Pharmacy and Pharmaceutical Sciences, 2018. 10:122127.

14. Weisburg WG, Barns SM, Pelletier DA, Lane DJ: 16 S ribosomal DNA amplification for phylogenetic study. Journal of bacteriology, 1991. 173(2): p. 697-703.

15. Ban kỹ thuật tiêu chuẩn TCVN/TC147 "Chất lượng nước", Tiêu chuẩn Việt Nam TCVN 6001-1 : 2008 (ISO 5815-1 : 2003), Chất luợng nước-Xác định nhu cầu oxy sinh hóa sau n ngày (BODn) - Phần 1: phương pháp pha loãng và cấy có bổ sung allylthiourea. Bộ Khoa học và Công nghệ ban hành.

16. Ban kỹ thuật tiêu chuẩn TCVN/TC147 "Chất lượng nước", Tiêu chuẩn Việt Nam TCVN 6491: 1999 (ISO 6060: 1989), Chất lương nước - Xác định nhu cầu oxy hóa học. Bộ Khoa học và Công nghệ ban hành.

17. Lari Vähäsalo and Bjarne Holmbom, Reliable spectrophotometric determination of starch concentration in papermaking process waters. Nordic Pulp and Paper Research Journa, 2004. 19(1): p. 75-77.

18. Édilla Ribeiro dos Santos, Z.N.S.T., Núria Mariana Campos, Diogo Angeli Jacinto de Souza, Aline Simões da Rocha Bispo and Rodrigo Pires do Nascimento, Production of a-Amylase from Streptomyces sp. SLBA-08 Strain Using Agro-Industrial By-Products. Brazilian Archives Of Biology and Technology, 2012. 55(5): p. 793-800.

19. More SV, J.S., Rao BS, Nair BU, Laxman RS., Chromium removal and reduction in COD of tannery effluents by actinomycetes. Indian journal of environmental health, 2001. 43(3): p. 108-13. 